Archived version from NCDOCKS Institutional Repository http://libres.uncg.edu/ir/asu/

\title{
Appalachían
}

B O O N E, N O R T H C A R O L I N A

\section{The Relationship Between Service Learning And Undergraduate Social Work Students' Professional Value Development}

\author{
By: Denise Levy and Alisha Edmiston
}

\begin{abstract}
Service learning has long been used to foster students' personal and professional development and encourage civic engagement. This study explored how service learning affected the development of professional values in undergraduate social work students, with a focus on the core values of the profession outlined by the National Association of Social Workers. Thirty-six students enrolled in a service-learning course with 30 hours of required service in an agency completed a survey at the end of the semester. The majority of respondents reported observing a slight or significant increase for them personally in each of the core values as a result of the servicelearning experience. The core values of service and competence increased the most. Working with agency clients and participating in class discussions were the most helpful in the development of all the core values.
\end{abstract}

Levy, D. \& Edmiston, A. (2015). The Relationship Between Service Learning and Undergraduate Social Work Students' Professional Value Development. The Journal of Baccalaureate Social Work Program Directors, Volume 20, pages 137-155. Publisher version of record available at: https://doi.org/10.18084/1084-7219.20.1.137 


\title{
The Relationship Between Service Learning and Undergraduate Social Work Students' Professional Value Development
}

\author{
DENISE LEVY \\ ALISHA EDMISTON
}

Service learning has long been used to foster students' personal and professional development and encourage civic engagement. This study explored how service learning affected the development of professional values in undergraduate social work students, with a focus on the core values of the profession outlined by the National Association of Social Workers. Thirty-six students enrolled in a service-learning course with 30 hours of required service in an agency completed a survey at the end of the semester. The majority of respondents reported observing a slight or significant increase for them personally in each of the core values as a result of the servicelearning experience. The core values of service and competence increased the most. Working with agency clients and participating in class discussions were the most helpful in the development of all the core values.

KEYWORDS service learning, professional values, core values

\begin{abstract}
Before entering this course I practiced and believed in the core values of social work. However, after this experience, it seems that I want to do even more for people. I am thinking of new ways to help and find resources, and researching on my own time. I am very excited to start my journey as a social worker.

—BSW student/participant in the study
\end{abstract}

Service learning, as the name implies, addresses community and educational needs. The term arose in the 1960s during a time when service programs such as the Peace Corps and VISTA (Volunteers in Service to America) were popular among college students (Phillips, 2011). Bringle and Hatcher (1996) describe service learning as

a credit-bearing educational experience in which students participate in an organized service activity that meets identified community needs and reflect on the service activity in such a way as to gain further understanding of course content, a broader appreciation of the discipline, and an enhanced sense of civic responsibility. (p. 222) 
Service learning is also defined as "an intentional, structured tool for social change" (Nadel, Majewski, \& Sullivan-Cosetti, 2007, pp. 3-4). It includes three components: reflection, reciprocity, and civic engagement (Phillips, 2011).

Service learning is grounded in multiple theoretical perspectives: Dewey's theory of education, Kolb's experiential learning theory, and Mezirow's transformational learning theory (Cronley, Madden, Davis, \& Preble, 2014; Nino, Cuevas, Loya, 2011). All of these theorists connect learning with experience in some way. Dewey (1938) describes a strong connection between experience and education, explaining that educators should facilitate experiential learning in order for students to reach their full potential. Based on Dewey's theory, Kolb (1984) proposed a cyclical model of experiential learning that includes having an experience, critically reflecting on that experience, forming abstract concepts, and experimenting with new concepts. His theory is based on the idea that knowledge comes from and is grounded in our experiences. Finally, Mezirow's $(1991,1995)$ transformational learning theory proposes that disorienting experiences may result in a process of reflection, discourse, action, and ultimately transformation. Dewey, Kolb, and Mezirow all acknowledge the important role experience plays in learning.

In service learning, students' experiences in community agencies as well as their reflections on those experiences can affect and transform them in many ways. As they learn from their experiences, students in service-learning courses begin to identify their values and understand themselves in new ways (Kronick \& Cunningham, 2013; Lemieux \& Allen, 2007). They also develop skills related to self-awareness, critical thinking, problem solving, interpersonal communication, civic involvement, leadership, and cultural competence (King, 2003; Lemieux \& Allen, 2007; Phillips, 2011). In short, students develop personally and professionally as a result of service-learning experiences (Belliveau, 2011).

Several studies have found that students developed professional values as a result of their service-learning experiences (Ericson, 2011; Maccio $\varepsilon$ Voorhies, 2012; Nadel et al., 2007; Williams \& Reeves, 2004). However, these studies focused broadly on student learning outcomes, of which professional value development was sometimes a result. Focused specifically on the development of the core values of the National Association of Social Workers (NASW), this study answers the call of Williams and Reeves (2004) to further explore how students develop professional social work values during servicelearning experiences.

This study explored how service learning affected the development of professional values in undergraduate social work students. Specifically, the study focused on the core values of the profession specified by the NASW: 
service, social justice, the dignity and worth of the person, the importance of human relationships, integrity, and competence. Thirty-six social work majors enrolled in a service-learning course with 30 hours of required service in an agency completed a survey at the end of the semester. Students provided information about how they developed professional values as a result of their service-learning experiences and about which aspects of the service-learning course were most helpful in value development.

\section{Service Learning and Social Work Education}

Because service learning and social work education focus on similar values such as service, civic engagement, and personal and professional development, they seem like a natural pairing. However, social workers have been notably absent from service-learning conferences and federal projects (Nadel et al., 2007). Even within the profession, discussion of civic engagement and service learning has been sporadic until the last decade (Nadel et al., 2007). Still, service learning has been used in social work education in various ways to foster students' personal and professional development and encourage civic engagement (Belliveau, 2011; Ericson, 2011; Jones, 2011; Lowe \& Clarke, 2012; Lucas-Darby, 2011; Maccio \& Voorhies, 2012; Mink \& Twill, 2012; Rocha, 2000; Stepteau-Watson, 2012; Twill, Elpers, E Lay, 2011; Williams \& Reeves, 2004). This includes undergraduate and graduate courses; introductory social work classes; courses focused on theory, social welfare, research, and policy; micro, mezzo, and macro practice classes; and specialized electives (Cronley et al., 2014; Phillips, 2011).

What does service learning entail in social work education? Twill et al. (2011) explain that "service-learning in social work courses should include connecting and collaborating with a community partner so that the students and community partner benefit in a meaningful way from the service-learning activity and uphold the values and ethics of the profession" (p. 50). They go on to say that courses should include critical reflection that encourages personal and professional development. Similarly, Tapp and Macke (2011) state that service learning values the primacy of community needs and allows the development of learning experiences based on those community needs. Further, credit-based service-learning courses include reflective exercises that connect the service experience to "course content, the profession, and civic responsibility" (p. 78).

Service learning is similar in some ways to volunteer work and field education. In volunteer work and service learning, for instance, the community agency, not the educational institution, identifies the service 
needs (Tapp \& Macke, 2011). Service learning also shares similarities with field education, which is considered the signature pedagogy in social work education. Both are course based, and students earn credit for their service components (Tapp \& Macke, 2011). In fact, because of the similarities between the two, several authors conclude that service learning helps to prepare students for internships (Belliveau, 2011; Kronick \& Cunningham, 2013; Twill et al., 2011), and one study suggested incorporating servicelearning capstone projects into field placements (Tapp \& Macke, 2011).

Despite these similarities, there are distinct differences between volunteer work, service learning, and field education. On a continuum from volunteer work to educational internships, service learning lies somewhere in the middle (Cronley et al., 2014). Lemieux and Allen (2007) state that volunteer work focuses primarily on service, field education focuses primarily on student learning, and service learning equally emphasizes community needs and student development. Similarly, Phillips (2011) notes that unlike volunteer and fieldwork, service learning includes intentional learning outcomes and reciprocal university-community relationships. For instance, in field placements, students often begin the placement by forming learning goals and objectives based on competencies and practice behaviors they must demonstrate. In service learning, students start with community needs and then form learning goals and objectives based on those needs. Although students certainly learn from all their course work and co-curricular experiences, service-learning courses are uniquely positioned to promote professional value development in social work majors because of their distinct focus on learning outcomes and community needs.

\section{Professional Value Development in Service-Learning Social Work Courses}

Described in detail by NASW (2008), the six core values of the profession are service, social justice, the dignity and worth of the person, the importance of human relationships, integrity, and competence. According to NASW, social workers value service by focusing their practice on helping people and communities in need. Social workers advocate for social justice by challenging poverty and discrimination, promoting understanding of diversity, and working for equality. Respecting the dignity and worth of the person, social workers encourage self-determination and treat people with respect and care. Social workers also value human relationships, engaging people to promote individual and community well-being. Practicing with integrity, social workers are trustworthy, responsible, and ethical. Finally, social workers are competent, benefitting from and contributing to professional knowledge. 
The Council on Social Work Education (CSWE, 2008) charges social work programs to ground their implicit and explicit social work curriculum in NASW's core values. Further, programmatic outcomes must include competencies and practice behaviors related to these core values (CSWE, 2008). Social work students should not only learn about the professional values, they must also integrate these into their practice with individuals, groups, families, and communities. Thus, the curriculum must include a discussion of personal and professional identities and values (Osteen, 2011).

Social work students may initially have difficulty understanding how professional values guide practice and may even have difficulty in identifying their own values (Woodward \& Mackay, 2012). However, experiential learning and interactions with classmates can assist them with understanding personal and professional values (Woodward \& Mackay, 2012). For instance, Sullivan $E$ Johns (2002) propose a 4-hour experiential workshop that includes games/dilemmas, discussion, and instruction to teach social justice and address issues of racism and discrimination. Lindsey (2005) describes how a study-abroad experience facilitated development of professional identity and values such as social justice.

Service learning in particular can assist social work students in developing their professional values. Because service-learning courses include the iterative process of learning, doing, and reflecting, students have the opportunity to develop and value competence and integrity. Further, because service-learning experiences are developed based on community needs, they encompass the values of service, social justice, human relationships, and the dignity and worth of the person. Indeed, "service learning embodies specific social work values, such as respect for diversity, self-determination, collaboration, social justice, a person-in-environment focus, and accountability" (King, 2003, p. 37). It also encourages self-determination, collaboration, and accountability (Mink \& Twill, 2012). In service-learning courses, students become more self-aware and learn to start "where the client is" (King, 2003, p. 41). They also see the impact of social policies and learn to challenge social injustice (King, 2003). This type of professional value development is especially important in social work education.

\section{Review of the Literature}

A handful of studies explore the connection between service-learning courses and professional value development in social work education. Williams and Reeves (2004) found that service learning had an impact on MSW students' professional value development. Specifically, 21 MSW students who volunteered at a week-long camp for children with burn injuries reported the 
development, application, and integration of four core values: the importance of human relationships, integrity, service, and social justice (Williams $\mathcal{E}$ Reeves, 2004).

Ericson (2011) found that international service-learning courses helped students develop competencies related to social justice and service. A total of 29 undergraduate students participated in two international servicelearning courses in Costa Rica for 3 weeks each and completed a survey based on their experiences. Survey results "indicated that students believed more strongly that they could have an impact on the world and showed an increased sense of responsibility to do so" (Ericson, 2011, p. 74). Further, students not only believed in themselves as change agents, they also strengthened their belief in others to influence society.

Maccio and Voorhies (2012) found that a diversity course with a servicelearning approach helped students see the value in service and in issues of diversity (social justice). They surveyed 45 graduate social work students in two sections of the course and found that "students most liked servicelearning for its focus on serving others... . Students were able to see outside themselves and appreciate that their efforts helped others" (p. 55). The service-learning course assisted students in understanding the "bigger picture" (p. 55) of how serving individuals can make an impact on an organization and community.

In Nadel et al. (2007) several service-learning courses were presented that assisted students in developing professional values. The instructor of an Introduction to Social Work course at Nazareth College, in Rochester in New York, formed a partnership with a youth development agency; as a result of their experiences at the agency and a reflective writing assignment, students were able to identify personal and professional values and become more selfaware (Watkins, Charlesworth, \& House, 2007). At a summer camp for families affected by HIV, students in a service-learning course examined their personal values and developed their professional values (Nadel, 2007). After completing a service-learning course on a Lakota Nation reservation, students were more concerned about and more involved in challenging social injustices faced by native populations (Majewski \& Turner, 2007).

Certainly, many other service-learning instructors address social work values and value development without mentioning it specifically in their scholarly articles. For instance, Jones (2011) writes that her students learned about the process of building relationships, became more comfortable in their interactions with agency clients, and demonstrated respect and interpersonal skills. Although not explicitly named, the core values of competence, the importance of human relationships, and the dignity and worth of the person are evident in these outcomes. 
Although all these studies found that students developed professional values as a result of their service-learning experiences, they were all focused generally on what students learned during the courses. In other words, none specifically studied how students' core values developed as a result of their service-learning experiences. Therefore, additional research is needed to explore how students develop their values during service-learning experiences (Williams \& Reeves, 2004) and to determine which professional values are affected by service learning. The broad purpose of this study was to determine how a service-learning experience had an impact on the development of professional values in undergraduate social work students and included the following research questions:

-Do undergraduate social work students report that they identify with professional values more after their service-learning experience?

-What aspects of the service-learning experience foster the development of professional values?

-Does professional value development differ based on the demographic factors of the service-learning agency, the student, or both?

\section{Methodology}

This study took place at a 4-year public university with an enrollment of about 17,000 students. In the latest review by the Carnegie Foundation, the university once again received the Community Engagement classification. Reviewed every five years, this classification requires reciprocal collaboration between the university and the community to "enrich scholarship, research, and creative activity; enhance curriculum, teaching and learning; prepare educated, engaged citizens; strengthen democratic values and civic responsibility; address critical societal issues; and contribute to the public good" (Carnegie Foundation, n.d., "How Is 'Community Engagement' Defined?" para. 2). Indeed, the university has a long-standing history of partnership and involvement with the community and has a nationally recognized office dedicated to that purpose. The social work program staff have been involved in service-learning efforts at the university from the beginning, and the department also offers at least one service-learning course each semester.

This study focused on a particular service-learning course offered by the university's Department of Social Work. The course is an introductory practice course teaching basic skills, and students earn letter grades (A-F). This 300level undergraduate course is required for social work majors, and it is the only course at this level open to non-majors. The course provides information 
about effective relationship, communication, interviewing, and recording skills, and students are required to demonstrate these interpersonal skills in their service-learning agencies and in a videotaped interview. Although the course is open to non-majors, it is grounded in social work theory and practice, and is distinctly a social work course. Most non-majors who take the course are psychology majors with a minor in social work, or they are social work minors. This study focuses only on the social work majors enrolled in the course. It is important to note that social work majors in this course are at a critical point in their curriculum because this is when they apply to move into the upper-level courses. In fact, the BSW program director and field director visit social work majors in each section of this course to talk to them about applying for the upper-level courses and to discuss the difference between service learning and field, and the academic standards of the program. $^{1}$

Service learning is a significant part of this course. Many of the students have agencies in mind for service learning when they begin the course, and all agencies are approved by the course instructor. The university office dedicated to service learning also assists students in locating an agency. In fact, because this course is an approved and designated service-learning course, the university-wide office provides support for students and instructors through community partnerships and contacts, sample forms, liability insurance, a service-learning library, and evaluations specific to service learning. This support is important because service-learning courses often require more time and effort from students and instructors alike. In this course, students are encouraged to distribute their 30 service-learning hours evenly throughout the entire semester to improve learning outcomes and enhance the iterative process of learning, doing, and reflecting.

Students in the course turn in service-learning agreements outlining their learning goals and objectives, time logs indicating they put in at least 30 hours of service learning in a community agency, and supervisor evaluations at the end of the semester. Additional assignments related to service learning include self-awareness homework exercises focused on basic skills, smallgroup reflection forums connecting course content with service-learning experiences, and journal assignments. The service-learning journal in particular provides students with the opportunity to reflect on their servicelearning experiences while improving their self-awareness, interpersonal skills, and documentation. Students use the behavior/impression/plan system to document what happened at the agency using behavioral indicators (B); their impressions, feelings, and opinions about what happened (I); and what they learned from the situation and plan to improve in the future (P). 
In addition to service-learning content the course includes information related to the core values of the profession. Students in the course begin to understand their own values using self-reflection and learn to apply core professional values in the classroom and in the service-learning agency. Experiential learning is strongly emphasized in the course, and students learn by observing, doing, and reflecting.

For this study, approved by the university's institutional review board, social work majors enrolled in three sections of the 300-level service-learning course and were invited to complete an online survey at the end of the course. Two sections were offered on campus and one was offered in a faceto-face distance education site about 1 hour from the main campus. Of the 76 students enrolled in the three sections of this course, 58 were social work majors. Of the 58 social work majors, 36 (62\%) completed the survey. The survey asked students to rate how their professional values changed as a result of their service-learning experience, with one question for each of the six core values. For example, for the item "As a result of my service learning experience, I value social justice...," students selected a response on a 5point Likert scale from significantly less than before to significantly more than before. Students could also choose the response N/A: I do not hold this value. However, none of the students selected this option for any of the core values.

Students who reported an increase in value (slightly more than before or significantly more than before) were asked which course factors prompted these changes. Factors included course lectures, guest speakers, textbook or readings, class discussions, reflective journal entries, discussions with the agency supervisor, discussions with the agency staff, working with agency clients, or other factors.

Demographic information about the students, the agency, and the agency supervisor were also collected. This included students' race, gender, age, religion or worldview, amount of previous human service experience, cohort (on campus or distance), and completion of other social work courses (see Table 1). Consistent with the region, the university enrollment, and the demographics of social work majors, a majority of respondents were White, female, Christian, and had completed or were enrolled in the other foundation social work courses. Nearly $60 \%$ of students were on campus and $40 \%$ at the distance location. The average age was about 24 , and the average amount of previous human service experience was about 5 years.

Agency and supervisor demographics included the agency type and the supervisor's educational background (see Table 2). Students completed service-learning hours in a variety of human service agencies, with the 
Table 1 Student Demographic Variables

\begin{tabular}{|c|c|c|}
\hline Variables & $n$ & $\%$ \\
\hline \multicolumn{3}{|l|}{ Race } \\
\hline White & 30 & 83.3 \\
\hline Black & 2 & 5.6 \\
\hline Biracial & 1 & 2.8 \\
\hline Asian & 1 & 2.8 \\
\hline Did not report & 2 & 5.6 \\
\hline \multicolumn{3}{|l|}{ Gender } \\
\hline Female & 32 & 88.9 \\
\hline Male & 4 & 11.1 \\
\hline \multicolumn{3}{|l|}{ Age } \\
\hline 19 & 3 & 8.3 \\
\hline 20 & 10 & 27.8 \\
\hline 21 & 6 & 16.7 \\
\hline 22 & 2 & 5.6 \\
\hline 24 & 4 & 11.1 \\
\hline 27 & 2 & 5.6 \\
\hline 29 & 1 & 2.8 \\
\hline 32 & 2 & 5.6 \\
\hline 35 & 1 & 2.8 \\
\hline 37 & 1 & 2.8 \\
\hline 38 & 1 & 2.8 \\
\hline 49 & 1 & 2.8 \\
\hline \multicolumn{3}{|l|}{ Religion } \\
\hline Christian & 26 & 72.2 \\
\hline Spiritual & 4 & 11.1 \\
\hline Agnostic, atheist, not religious & 6 & 16.7 \\
\hline \multicolumn{3}{|l|}{ Years of Experience } \\
\hline 0 & 5 & 13.9 \\
\hline 1 & 4 & 11.1 \\
\hline 2 & 6 & 16.7 \\
\hline 3 & 5 & 13.9 \\
\hline 4 & 1 & 2.8 \\
\hline 5 & 1 & 2.8 \\
\hline 6 & 1 & 2.8 \\
\hline 7 & 1 & 2.8 \\
\hline 8 & 1 & 2.8 \\
\hline 9 & 2 & 5.6 \\
\hline 10 & 10 & 13.9 \\
\hline \multicolumn{3}{|l|}{ Cohort } \\
\hline On Campus & 21 & 58.3 \\
\hline Distance & 15 & 41.7 \\
\hline \multicolumn{3}{|l|}{ Courses Taken } \\
\hline Foundational social work course A & 34 & 94.4 \\
\hline Foundational social work course B & 34 & 94.4 \\
\hline Foundational social work course C & 35 & 97.2 \\
\hline Foundational social work course D & 33 & 91.7 \\
\hline All foundation courses (A-D) & 30 & 83.3 \\
\hline Upper-level social work course E & 1 & 2.8 \\
\hline
\end{tabular}


Table 2 Agency Demographic Variables

\begin{tabular}{lcc}
\hline Variables & $n$ & $\%$ \\
\hline Agency type & & \\
Aging & 8 & 22.2 \\
Child welfare & 7 & 19.4 \\
Health & 6 & 16.7 \\
Poverty and homelessness & 5 & 13.9 \\
School & 4 & 11.1 \\
Disabilities & 2 & 5.6 \\
Criminal justice & 1 & 2.8 \\
Mental health & 1 & 2.8 \\
Community organizing & 1 & 2.8 \\
Agency supervisor & & \\
BSW social worker & 7 & 19.4 \\
MSW social worker & 9 & 25 \\
Other & 20 & 55.6 \\
\hline
\end{tabular}

majority located in health, gerontology, and child welfare. According to the students, about $55 \%$ of their supervisors were not social workers, about $25 \%$ were MSW social workers, and about $20 \%$ were BSW social workers.

The survey was primarily quantitative. However, respondents were also invited to share any qualitative information they deemed important regarding their development of core values during their service-learning experience. Only 17 students provided qualitative information, and, therefore, it was difficult to draw any conclusions from this data.

\section{Results}

The majority of respondents identified a slight or significant increase for each of the core values as a result of the service-learning experience (see Table 3). The core values of service and competence increased the most.

Overall, there were few significant differences based on students' demographics or the agencies' demographics. First, we tested for demographic differences in each of the six core values. One-way analysis of variance tests found no significant differences in professional value development based on years of human service experience or age. ${ }^{2}$ Similarly, there were no significant differences in professional value development based on previous social work coursework. ${ }^{3}$ Finally, there were no significant differences in professional value development based on race, gender, cohort, agency type, or supervisor type. ${ }^{4}$ Because almost all the students reported that their professional values increased slightly or significantly as a result of 
Table 3 Changes in Core Values as a Result of the Service-Learning Experience

\begin{tabular}{|c|c|c|}
\hline Variables & $n$ & $\%$ \\
\hline \multicolumn{3}{|l|}{ Service } \\
\hline Value the same as before & 6 & 16.7 \\
\hline Value slightly more than before & 6 & 16.7 \\
\hline Value significantly more than before & 24 & 66.7 \\
\hline \multicolumn{3}{|l|}{ Social justice } \\
\hline Value the same as before & 5 & 13.9 \\
\hline Value slightly more than before & 15 & 41.7 \\
\hline Value significantly more than before & 16 & 44.4 \\
\hline \multicolumn{3}{|l|}{ Dignity and worth of the person } \\
\hline Value the same as before & 7 & 19.4 \\
\hline Value slightly more than before & 11 & 30.6 \\
\hline Value significantly more than before & 18 & 50 \\
\hline \multicolumn{3}{|l|}{ Importance of human relationships } \\
\hline Value the same as before & 6 & 16.7 \\
\hline Value slightly more than before & 12 & 33.3 \\
\hline Value significantly more than before & 18 & 50 \\
\hline \multicolumn{3}{|l|}{ Integrity } \\
\hline Value the same as before & 9 & 25 \\
\hline Value slightly more than before & 10 & 27.8 \\
\hline Value significantly more than before & 17 & 47.2 \\
\hline \multicolumn{3}{|l|}{ Competence } \\
\hline Value the same as before & 5 & 13.9 \\
\hline Value slightly more than before & 9 & 25 \\
\hline Value significantly more than before & 22 & 61.1 \\
\hline
\end{tabular}

Note: range of choices for each value was as follows: significantly less than before, slightly less than before, the same as before, slightly more than before, significantly more than before, and N/A: I do not hold this value. Only those choices selected by respondents are shown in the table.

the service-learning experience, there was little variation with which to test group differences. Interestingly, although there were no significant differences in professional value development based on religion, ${ }^{3}$ differences did emerge when clustering students as Christian and non-Christian for the development of the importance of human relationships $(p=.046){ }^{2}$ Christian students valued the importance of human relationships more $(M=3.46)$ after service learning as compared to non-Christian students $(M=2.89)$.

In addition to testing differences for each of the core values, we also tested for demographic differences on a combined value variable. This variable was calculated by coding each core value as a dummy variable ( 0 for no increase in the value and 1 for slight or significant increase in the value) and adding the six dummy variables to create a composite score. Scores 


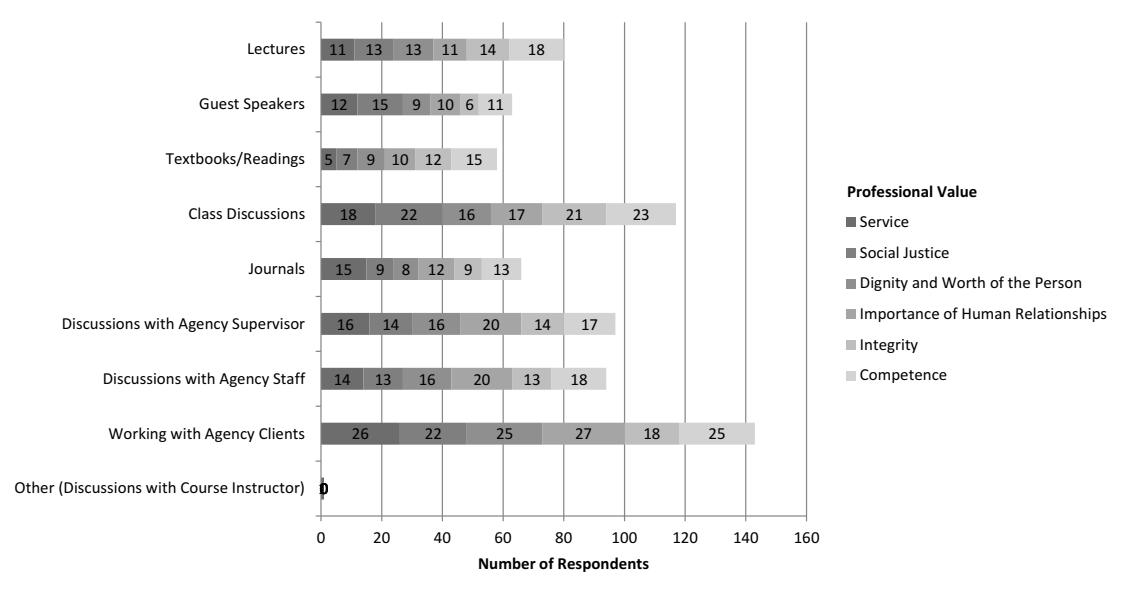

ranged from 0 to 6 with a mean of 4.94 . There were no significant differences among demographic groups in the combined professional value development variable.

Students who reported an increase (slight or significant) in professional values were also asked to select all the aspects of service learning that were helpful to their professional value development. For each core value, respondents selected all the factors that were helpful; these included lectures, guest speakers, textbook/readings, class discussions, supervisor discussion, reflective journals, staff discussions, working with clients, and others (see Figure 1). Students reported that working with clients and class discussions were the most helpful in the development of each of the six core values. Additionally, for the core values of competence and dignity and worth of the person, students reported that discussions with supervisors and agency staff were helpful. Although some students found lectures, guest speakers, textbook/readings, and journal entries to be helpful, these were not identified as often as other factors.

\section{Discussion}

Similar to the results of prior studies (Ericson, 2011; Maccio \& Voorhies, 2012; Nadel et al., 2007; Williams \& Reeves, 2004), the majority of the respondents in this study reported that the increase in professional values was a result of 
their service-learning experience. One said that "it is essential to engage in experience through activities such as service learning in order to have a greater understanding" of the core values. Another student stated that "service learning provides us with the opportunity to see all of the core values being used in a real life situation."

Of all the core values, respondents in this study reported that the core values of service and competence increased the most. It is not surprising that students value service more as a result of their service-learning experiences. Other studies show an increase in the value of service after taking servicelearning courses (Ericson, 2011; Maccio and Voorhies, 2012; Williams \& Reeves, 2004), and students find value in the service they are doing as part of their courses.

Although other studies do not highlight the increased value of competence, respondents in this study valued competence more as a result of their service-learning experiences. As students worked with clients in their service-learning agencies, competence emerged as an important component to their work and something they strived to achieve. One student said that she "gained more competence in speaking with people of all different backgrounds" as a result of her service-learning experience.

Although there were no significant differences in professional value development based on most student and agency demographic factors, differences did emerge in the core value of the importance of human relationships when clustering students as Christian and non-Christian. Christian students reported developing this value more than non-Christian students as a result of service learning. Whether this creates, narrows, or widens a disparity in expression of this value between Christian and nonChristian students is unclear based on the present findings. Future research should investigate these relationships further.

When asked about the factors that were most helpful in the development of professional values, students identified working with agency clients and class discussions. One student said, "the readings and discussions we had in class are very important, but to really understand these values, meeting and working closely with clients was essential." These two factors, working with clients and class discussions, highlight the service and learning aspects of service-learning courses. Taken together, they assisted students in developing the professional values of service, social justice, the dignity and worth of the person, the importance of human relationships, integrity, and competence. This finding may point to the significance of an iterative process of learning, doing, and reflecting. Future research should examine these factors and interactions to better understand what makes a difference for students in developing professional values. 
Finally, although journals were not identified as helpful to students in this study, it is important to note that the journal assignments were general reflections and did not require a specific focus on professional values. Adding a journal assignment focused on professional values may enhance the use of reflective journals in service-learning courses.

\section{Implications}

Regarding the implications for service-learning courses, students in this study identified the "hands-on experience" of working with clients coupled with discussions in their service-learning class as being important components in their professional value development. Instructors teaching service-learning courses can encourage direct client contact and incorporate class discussions to facilitate professional value development.

These findings also have implications for social work education and curriculum design. Students in this service-learning course had foundational knowledge of the core values of the profession. Given this foundational knowledge, the service-learning course provided the structure and opportunity for professional value development prior to the educational internship. In other words, service-learning courses may be a helpful bridge for students prior to their field placements. Additionally, university-wide offices dedicated to civic engagement or service learning provide valuable resources for instructors and students; their assistance often makes servicelearning courses possible.

\section{Limitations and Future Research}

There are several limitations to this study. First, given the exploratory nature of the study, students were only surveyed at the conclusion of the course. Future research should include pre- and posttests to better compare students' professional values at the start and end of the semester.

This study also included a small sample $(n=36)$, and the results are not generalizable to other social work students or service-learning courses. Future research should build upon this small sample and, in particular, include more diverse respondents. This study, consistent with the population of the region, university, and social work program, included mostly White, Christian, female respondents.

In addition to addressing the limitations of this study, future research should explore which specific aspects of working with clients and class discussions are helpful to students. In particular, it will be helpful to further study working with clients, class discussions, and the iterative process of 
learning, doing, and reflecting. Journal entries focused specifically on professional values should be explored as a way to assist students in professional value development. Finally, future research is needed in learning about how professional value development affects students' personal values in service-learning experiences.

\section{Conclusion}

The social work literature on service learning is sparse, and social workers have been mostly absent from conversations on service learning. To address this gap in the literature, this exploratory study sought to understand how service learning affected the development of the core values of the social work profession outlined by NASW. The broad purpose of this study was to determine how a service-learning experience had an impact on the development of professional values in undergraduate social work students and included the following research questions:

- Do undergraduate social work students report that they identify with professional values more after their service-learning experience?

-What aspects of the service-learning experience foster the development of professional values?

- Does professional value development differ based on the demographic factors of the service-learning agency, the student, or both?

Findings indicate that as a result of their service-learning experiences, social work undergraduate students in this study developed greater internalization of all six of the core values. Students identified class discussions and working with clients as the most helpful factors in professional value development. For the most part, there were no significant differences in value development based on student or agency demographics. Because of the limitations of this study, continued exploration of how students develop their values during service-learning courses is necessary to gain a better understanding of the process.

\section{References}

Belliveau, M. (2011). Interdisciplinary service-learning: Building student competencies through the cross-cultural parent groups project. Advances in Social Work, 12, 79-93.

Bringle, R. G., \& Hatcher, J. A. (1996). Implementing service learning in higher education. Journal of Higher Education, 67(2), 221-239. 
Carnegie Foundation. (n.d.). Community engagement elective classification. Retrieved from http://nerche.org/index.php?option=com_contentEview $=$ articleEid $=341$ Eltemid $=92$

Council on Social Work Education. (2008). Educational policy and accreditation standards. Retrieved from http://www.cswe.org/File.aspx?id=13780

Cronley, C., Madden, E., Davis, J., \& Preble, K. (2014). Factors influencing service-learning utilization in social work: Results from an online survey of faculty. Journal of Teaching in Social Work, 34, 147-166.

doi: 10.1080/08841233.2014.890692

Dewey, J. (1938). Experience and education. New York, NY: Macmillan.

Ericson, C. B. (2011). Pura vida with a purpose: Energizing engagement with human rights through service-learning. Advances in Social Work, 12, 63-78.

Jones, S. H. (2011). Life is experienced until we die: Effects of service-learning on gerontology competencies and attitudes toward aging. Advances in Social Work, 12, 94-112.

King, M. E. (2003). Social work education and service learning. Journal of Baccalaureate Social Work, 8(2), 37-48.

Kolb, D. (1984). Experiential learning: Experience as the source of learning and development. Englewood Cliffs, NJ: Prentice Hall.

Kronick, R. F., \& Cunningham, R. B. (2013). Service-learning: Some academic and community recommendations. Journal of Higher Education Outreach and Engagement, 17(3), 139-152.

Lemieux, C. M., E Allen, P. D. (2007). Service learning in social work education: The state of knowledge, pedagogical practicalities, and practice conundrums. Journal of Social Work Education, 43, 309-325.

Lindsey, E. W. (2005). Study abroad and values development in social work students. Journal of Social Work Education, 41, 229-249.

Lowe, L. A., E Clark, J. (2012). Learning about social work research through service learning. Journal of Community Engagement and Scholarship, 2(1), 50-59.

Lucas-Darby, E. T. (2011). The new color is green: Social work practice and service-learning. Advances in Social Work, 12, 113-125.

Maccio, E. M., E Voorhies, R. A. (2012). Social work students' perceptions of service learning. Journal of Service-Learning in Higher Education, 1, 50-69.

Majewski, V., \& Turner, A. D. (2007). Service learning for social justice: Mandate for long-term evaluation? In M. Nadel, V. Majewski, \& M. Sullivan-Cosetti (Eds.), Social work and service learning: Partnerships for social justice (pp. 181-194). New York, NY: Rowman \& Littlefield.

Mezirow, J. (1991). Transformative dimensions of adult learning. San Francisco, CA: Jossey-Bass. 
Mezirow, J. (1995). Transformation theory of adult learning. In M. R. Welton (Ed.), In defense of the lifeworld: Critical perspectives on adult learning (pp. 39-70). New York, NY: SUNY Press.

Mink, T., \& Twill, M. (2012). Using service learning to teach a social work policy course. Journal of Community Engagement and Scholarship, 5(1), 5-13.

National Association of Social Workers. (2008). Code of ethics. Retrieved from http://www.socialworkers.org/pubs/code/code.asp

Nadel, M. (2007). Populations-at-risk/Immersion experience: Service learning at summer camp. In M. Nadel, V. Majewski, \& M. Sullivan-Cosetti (Eds.), Social work and service learning: Partnerships for social justice (pp. 133-146). New York, NY: Rowman \& Littlefield.

Nadel, M., Majewski, V., \& Sullivan-Cosetti, M. (Eds.). (2007). Social work and service learning: Partnerships for social justice. New York, NY: Rowman $\varepsilon$ Littlefield.

Nino, M., Cuevas, M., \& Loya, M. (2011). Transformational effects of servicelearning in a university developed community-based agency. Advances in Social Work, 12, 33-48.

Osteen, P. J. (2011). Motivations, values, and conflict resolution: Students' integration of personal and professional identities. Journal of Social Work Education, 47, 423-443. doi:10.5175/ISWE.2011.20090C131

Phillips, A. (2011). Service-learning and social work competency-based education: A "goodness of fit"? Advances in Social Work, 12, 1-20.

Rocha, C. J. (2000). Evaluating experiential teaching methods in a policy practice course: The case for service learning to increase political participation. Journal of Social Work Education, 36, 53-63.

Stepteau-Watson, D. (2012). Infusing student activist into the college curriculum: A report of a service-learning project to bring awareness to sexual violence. College Student Journal, 46, 788-794.

Sullivan, E., \& Johns, R. (2002). Challenging values and inspiring attitude change: Creating an effective learning experience. Social Work Education, 21, 217-231. doi:10.1080/02615470220126444

Tapp, K., \& Macke, C. (2011). Competency-based capstone projects: Service learning in BSW field practica. Journal of Baccalaureate Social Work, 16(2), 75-91.

Twill, S. E., Elpers, K., \& Lay, K. (2011). Achieving HBSW competencies through service-learning. Advances in Social Work, 12, 49-62.

Watkins, M. L., Charlesworth, L., \& House, A. V. (2007). Social work practice: Nurturing beginning practice skills while mobilizing partnerships between youth development agencies and social work education. In M. Nadel, V. Majewski, \& M. Sullivan-Cosetti (Eds.), Social work and service learning: Partnerships for social justice (pp. 77-91). New York, NY: Rowman \& Littlefield. 
Williams, N. R., \& Reeves, P. M. (2004). MSW students go to burn camp: Exploring social work values through service-learning. Social Work Education, 23, 383-398. doi:10.1080/0261547042000245008

Woodward, R., E Mackay, K. (2012). Mind the gap! Students' understanding and application of social work values. Social Work Education, 31, 1090-1 104. doi:10.1080/02615479.2011.608252

\section{Endnotes}

${ }^{1}$ Several of the academic standards of the program mirror the profession's values. Academic standards include demonstrating professional identity, selfawareness, ethical behavior, interpersonal skills, and a commitment to diversity, social justice, and human rights.

${ }^{2}$ This held true when testing actual years of human service experience/actual age as well as ranges or clusters.

${ }^{3}$ This was tested with a Mann-Whitney $U$ test, a nonparametric test similar to a ttest that analyzes differences between two groups on an ordinal dependent variable (professional value development for each core value).

${ }^{4}$ These were tested with a Kruskal-Wallis $\mathrm{H}$ test, a nonparametric test of differences in means between three or more groups on an ordinal dependent variable (professional value development for each core value). We tested race by all reported races and as White/non-White, the latter using a Mann-Whitney $\mathrm{U}$ test.

Denise Levy, PhD, is associate professor and MSW program director at Appalachian State University, and Alisha Edmiston is placement coordinator at the Bair Foundation in Las Cruces, New Mexico. 